\title{
Basic Principles of HIV
}

Intervirology

\section{Targets for Inhibition of HIV Replication: Entry, Enzyme Action, Release and Maturation}

\author{
Saleta Sierra-Aragón ${ }^{a}$ Hauke Walter ${ }^{b}$ \\ ${ }^{a}$ Institute of Virology, University of Cologne, Cologne, and ${ }^{b}$ Institute of Virology, University of Erlangen-Nürnberg, \\ Erlangen, Germany
}

\section{Key Words}

Antiretroviral therapy $\cdot$ Retroviral targets $\cdot$ HIV replication inhibition $\cdot$ Drug resistance classes are still a major problem. Additional targets will have to be defined to achieve the ultimate goal: the eradication of the virus from the infected human body.

Copyright $\odot 2012$ S. Karger AG, Basel

\begin{abstract}
Inhibition of HIV replication initially targeted viral enzymes, which are exclusively expressed by the virus and not present in the human cell. The development of reverse transcriptase (RT) inhibitors started with the discovery of antiretroviral activity of the nucleoside analog zidovudine in March 1987. Currently, six major classes of antiretroviral drugs are used for the treatment of HIV-infected patients: the RT inhibitors, nucleoside inhibitors and nonnucleoside inhibitors, the protease inhibitors, the integrase inhibitor raltegravir, the fusion inhibitor enfuvirtide (T-20), and the chemokine receptor 5 antagonist maraviroc. A seventh class, the maturation inhibitors, has not yet been approved as their effectiveness is impaired by HIV-1 polymorphisms naturally occurring in $30-$ $40 \%$ of HIV-1 therapy-naive isolates. The use of antiretroviral combination therapy has proven to be effective in delaying progression to AIDS and to reconstitute the immune system of HIV-infected individuals. During the last 5 years, the introduction of the newest antiretrovirals has increased treatment efficacy tremendously. However, the development and accumulation of resistance to all antiretroviral drug
\end{abstract}

\section{Introduction}

After the first description of the novel acquired immune deficiency syndrome (AIDS) and identification of its causal agent HIV, the urgent need for antiretroviral therapy was obvious. At that time, options for antiviral therapy were generally limited: there was amantadine against influenza virus A or the nucleoside analog aciclovir against alpha herpes viruses, but no antiretrovirals had been identified yet.

The first ideas to target HIV aimed to inhibit viral enzymes, which are exclusively expressed by the virus and not present in the human genome: this is true for the reverse transcriptase (RT) and the integrase (IN) only. The development of RT inhibitors started with the discovery of the antiretroviral activity of the nucleoside analog zidovudine [AZT (azidothymidine)], quickly followed by other nucleoside analogs like didanosine (ddI), stavudine (d4T), and lamivudine (3TC). However, treatment with nucleosides was challenged by fast resistance develop-

\section{KARGER}

Fax +4161306 1234

E-Mail karger@karger.ch

www.karger.com
(C) 2012 S. Karger AG, Basel

0300-5526/12/0552-0084\$38.00/0

Accessible online at:

www.karger.com/int
Saleta Sierra-Aragón

Institute of Virology

Fuerst-Pueckler Strasse 56

DE-50935 Cologne (Germany)

Tel. +49 2214788 7261, E-Mail saleta.sierra-aragon@uk-koeln.de 
ment by the virus either in months, or, as in the case of $3 \mathrm{TC}$, in approximately $80 \%$ of all patients after only 2 weeks of monotherapy [1]. Therefore, two major rules of antiretroviral treatment have become evident: the inhibition of HIV replication by treatment is an achievable goal, and a resistant virus is selected in a very short time [2].

Supported by the reconstitution of AZT susceptibility in 3TC-resistant virus [2], the additive and synergistic effects of drug combinations could be observed. Antiretroviral therapy was further improved by the development and final approval of the first allosteric RT inhibitor [nonnucleoside RT inhibitor (NNRTI)] in the mid-1990s [3]. Several members of both drug classes were approved and are still in use today as a successful component of antiretroviral combination therapy.

Another major idea to inhibit HIV replication was to block the viral protease (PR), identified as essential for HIV replication [4]. In 1995, the approval of the first PR inhibitor (PI), saquinavir (SQV), led to a substantial enrichment of antiretroviral therapy. Combination therapy of two nucleoside analogs with a PI or an NNRTI was found to be superior in order to achieve sustained viral suppression [5,6]. A new era began, initially characterized by immune reconstitution in the majority of treated patients. However, this was limited by a high pill burden and side effects $[7,8]$. Today PIs are generally coadministered with low-dose ritonavir (RTV) as a pharmaceutical booster, which leads to increased and more stable drug levels, and to a drastic reduction of viral resistance development from approximately $50 \%$ of all observed therapeutic failures to $0-15 \%$ against all drugs $[9,10]$.

In 2003, enfuvirtide (T-20), the first and up to now only member of the fusion inhibitor class, was approved. Blocking viral entry should substantially reduce the loss of activated cells and the reseeding of cellular reservoirs. $\mathrm{T}-20$ is a peptide mimicking the viral fusion part of gp41 and interfering with trimer formation during an intraprotein conformation. Although the drug is quite effective and still successfully in use, its subcutaneous application limits clinical use to deep salvage regimens.

In 2007, maraviroc (MVC), the first chemokine receptor 5 (CCR5) antagonist, was approved. MVC is the first antiretroviral drug that does not bind to a viral but to a host protein. Development of drug resistance occurs in vivo by selection of X4-tropic variants. Nonetheless, the selection of R5 viruses resistant to CCR5 antagonists does rarely occur [11]. Therefore, it remains unclear if the choice of any cellular target is a sensible route to generally avoid resistance development. CCR5 antagonists have brought back an old puzzle still to be elucidated: the role of X4 viruses for disease progression. Are X4 viruses more pathogenic and does their presence contribute to causing AIDS, or do X4-tropic viruses appear preferentially when the immune system is already exhausted? In spite of the presence of minor X4 variants during early infection only detectable by ultradeep sequencing [12], most individuals progressed to late stages of infection harboring predominantly R5 viruses [8-10]. Additionally, the selection of X4 variants by CCR 5 antagonists did not lead to disease progression, indicating that X4-tropic variants are not necessarily more pathogenic than $\mathrm{R} 5 \mathrm{vi}$ ruses. This was further supported by the reappearance of R5 viruses when MVC was removed. Obviously, a competitive replication between $\mathrm{R} 5$ and $\mathrm{X} 4$ variants occurs.

In contrast to RT inhibitors, the development of inhibitors of the second specific viral enzyme, the IN, was more complicated $[13,14]$. The first IN inhibitor, the strand transfer inhibitor raltegravir (RAL) $[15,16]$, was approved in 2008.

Since 1995, the concept of combining several antiretrovirals has been proven to be effective in suppressing viremia and to enable patients to partially reconstitute their immune systems [17].

\section{Antiretroviral Therapy}

\section{Viral Entry Inhibitors}

HIV enters target cells with the help of the two envelope glycoproteins, gp120 and gp41. Both proteins have trimeric structures and together form spikes on the surface of the virions. The HIV entry process into a target cell is divided into three steps (fig. 1,2):

First, the virus attaches to the cellular membrane through interaction between the viral envelope protein gp120 and the first extracellular domain of the cellular CD4 receptor (D1 domain) [18-20]. Initial binding to CD4 causes a first change of gp120 conformation, which allows the presentation of the coreceptor binding site, a discontinuous epitope comprising the third hypervariable loop (V3), the $\beta-19$ strand and the bridging sheet of the gp120.

Second, the newly exposed gp120 region binds to the CCR5 or the CXCR4 coreceptor. Viral entry in the absence of CD4 expression has been reported and may occur rarely, but the presence of one of the coreceptors is crucial for the entry process [21]. Which coreceptor will be bound by the gp120 is mainly mediated by V3 loop sequence and glycosylation. A further conformational rearrangement then takes place, exposing certain domains of the second Env protein gp41. Gp41 is a highly conserved 


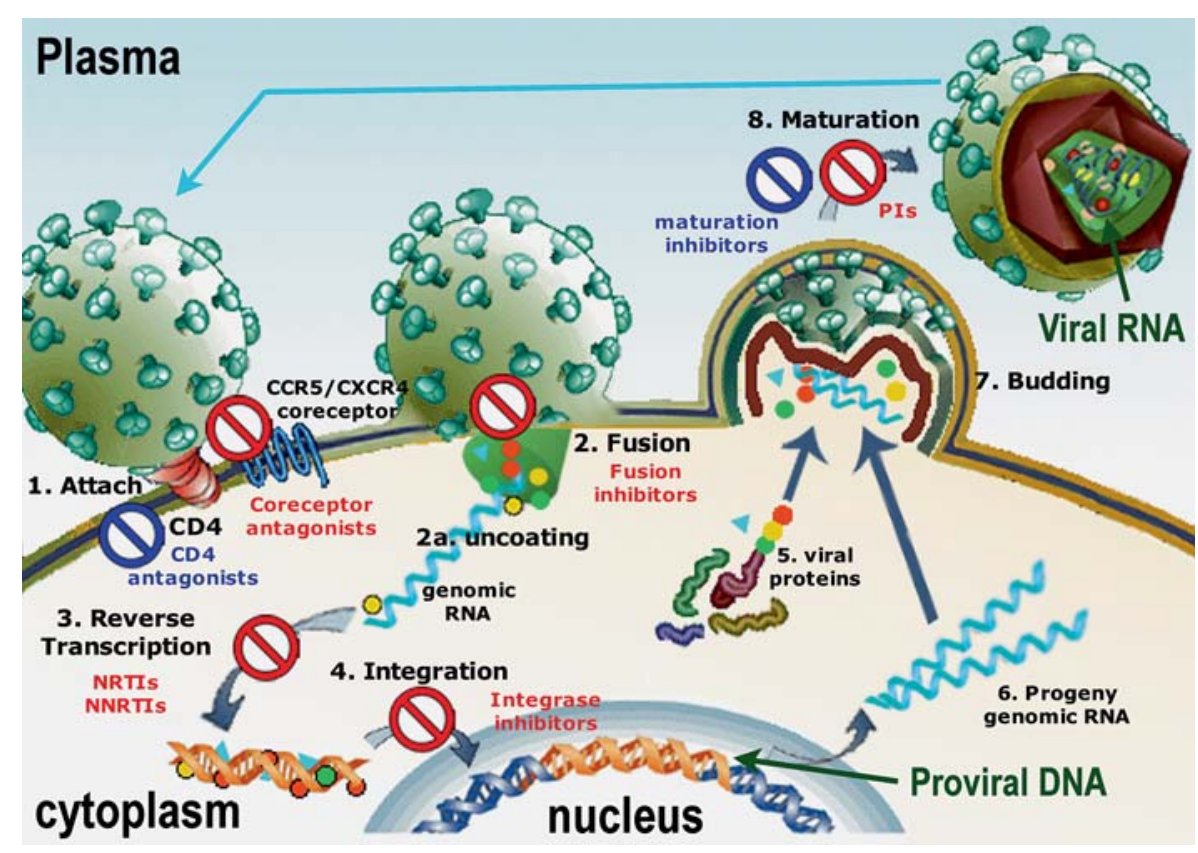

Fig. 1. HIV-1 life cycle and current targets for antiretroviral therapy. The virus attaches to the cell membrane via CD4 (1) and coreceptor binding, thereby initiating the fusion of viral and cellular phospholipid bilayers (2). After the entry, uncoating of the viral core begins (2a), soon followed by reverse transcription (3). The freshly formed preintegration complex is transported into the nucleus, where integration of the viral genome into the host genome occurs (4). The initially slow transcription results in translation of multiple-spliced viral mRNAs. The early proteins Tat and Rev optimize translation and nuclear export of single and unspliced viral
RNAs resulting in translation of viral glycoproteins and gag-(pol) precursor proteins (5). After the transfer of viral proteins and the unspliced viral genome (6) to the cell membrane, matrix-oriented parts of gag-(pol) precursors anchor in the membrane forming a spheric particle (7) budding from the cell membrane. Released particles are immature. The viral PR processes the gag and gag-pol proteins to originate a capsid, nucleocapsid and viral enzymes producing a mature virion able to infect a new cell. Main steps in the HIV-1 life cycle are indicated in black, approved antiretroviral drugs in red and drugs still undergoing clinical trials in blue.

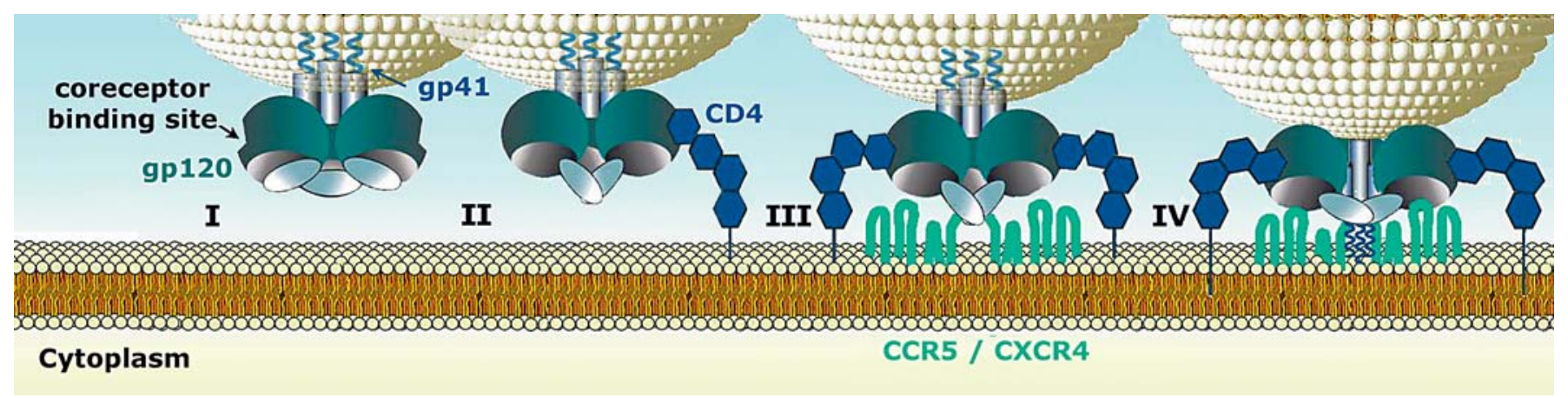

Fig. 2. Cell attachment. The viral gp120 (I) binds to the cellular receptor CD4 (II). This binding triggers a conformational change in gp120 that allows the exposition of the coreceptor binding site and interaction with the coreceptor CCR5 or CXCR4 (III). After binding to the coreceptor, a further conformational rearrangement exposes certain domains of the gp41 (IV) leading to the fusion of both cellular and viral membranes and release of the capsid into the cytoplasm. 
protein with a structure predominantly based on alpha helices and broad-sequence homologies to the type-1 fusion proteins of other viruses [22].

Third, the helical regions HR1 and HR2 of gp41 anchor in the cellular membrane and the N-terminal peptide initiates the fusion of both cellular and viral membranes and the liberation of the nucleocapsid to the cytoplasm [23-25].

\section{Inhibitors of CD4 Binding}

Blocking the interaction of CD4 and gp120 has been considered to develop the so-called attachment inhibitors. Initial approaches tried to develop neutralizing antibodies or soluble $\mathrm{CD} 4$ receptors that could prevent the virus from binding to the target cells [26]. Today it is known that none of the neutralizing antibodies exhibit an activity against a broad variety of HIV-1 isolates and that soluble CD4 receptors cannot reduce viral replication in vivo [27-29].

Some compounds are still under development and undergoing clinical trials [reviewed in 30]. These are humanized CD4-monoclonal antibodies binding to the cellular receptor and capable of hindering the interaction with gp120 or the conformational rearrangement necessary for the entry process. TMB-355 (TNX-355, Ibalizumab $^{\circledR}$, Tanox Biosystems), PRO-542 (Progenics Pharmaceuticals) or BMS-806 (BMS-488043, Bristol Myers Squibb) are examples of CD4 antagonists [31-37] (see also http://clinicaltrials.gov/ct2/show/NCT00784147 orhttp:// clinicaltrials.gov/ct2/show/NCT00055185).

\section{Inhibition of Coreceptor Binding}

Depending on the structure and charge of the coreceptor binding site of gp120, one or both of the chemokine receptors CCR 5 or CXCR4 can be recognized and docked $[19,20]$. Depending on this tropism, viruses were classified as R5 (those using exclusively CCR5 as a coreceptor), $\mathrm{X} 4$ (those using exclusively CXCR4 as a coreceptor) and R5X4 or dual-tropic viruses (able to use both coreceptors). Since HIV, like all RNA viruses, is present as a quasispecies in each infected individual $[38,39]$, mixtures of viruses with different tropism are frequently found (dualmixed viruses). However, phenotypic methods cannot discriminate between R5X4 and mixed viral populations; therefore, results were termed as dual-mixed viruses. Meanwhile, ultradeep sequence analyses derived from plasma samples have shown the presence of all kinds of tropic viruses in the quasispecies of an individual [40].
Current studies address the relevant maximum percentage of viruses in plasma, with tropism other than R5 that can lead to clinical therapy failure [41]. The standard diagnostic method for tropism testing is the bulk sequencing of the V3-loop sequence followed by an interpretation using the geno2pheno ${ }_{\text {[coreceptor] }}$ tool (www.genafor.org).

\section{CCR5 Antagonists}

Blocking the CCR5 receptor significantly hinders HIV replication and does not lead to any major side effects, as its functioning seems to be dispensable for normal immune cell activity in vivo. Approximately $1 \%$ of Caucasians are homozygous for a nonfunctional CCR5 receptor, carrying the so-called CCR5- $\Delta 32$-gene mutant alleles; they are healthy and partially resistant to HIV-1 R5 infection [42].

CCR5 antagonists interact with the host coreceptor, alter its structure and therefore hinder the recognition and binding of the viral gp120. As CCR 5 antagonists only interact with the CCR5 molecule, they are only effective against R5 viruses. The study A4001029 which analyzed the effect of MVC on X4 viruses showed no major differences in HIV-1 RNA decrease between the MVC and the placebo arms [43]. Therefore, a tropism test is mandatory before CCR 5 antagonist administration occurs.

MVC (Selzentry ${ }^{\circledR}$, Celsentri ${ }^{\circledR}$, ViiV Healthcare) is the first CCR5 antagonist approved for the treatment of R5carrying therapy-experienced patients [reviewed in 44]. MVC is primarily metabolized by CYP3A4, so its pharmacokinetics are affected by the inducers/inhibitors of this system, such as PIs (excluding tipranavir and fosamprenavir), efavirenz, etravirine or rifampicin, with recommendation for a dose adjustment when coadministered with these drugs $[45,46]$. The efficacy of MVC against $R 5$ virus has been tested in 3 trials [43, 47-53]. In very few cases, treatment failure has been described as a consequence of certain mutations in the $\mathrm{V} 3$ region that permit the virus to recognize the altered CCR5 and lead to resistance $[54,55]$. Usually, MVC therapy failure is associated with viral tropism switch.

Two other compounds of this drug class, aplaviroc and vicriviroc, that had reached clinical studies, have been withdrawn recently: aplaviroc (GlaxoSmithKline) due to severe side effects [56] and vicriviroc (Schering-Plough) because the primary efficacy endpoints have not been met. INCB9471 (Incyte), Pro-140 (Progenics Pharmaceuticals), and CCR5mAb004 (Human Genome Sciences) are other drugs under development [57-61] (see also http://clinicaltrials.gov/ct2/show/NCT00243230). In addition, aprepitant (Emend ${ }^{\circledR}$, Merck), an antiemetic be- 
longing to the neurokinin 1 (NK1) receptor blockers, has been tried for HIV-infected patients as it additionally downregulates the CCR5 coreceptor expression [62-64].

\section{CXCR4 Antagonists}

There is no genetic defect that leads to the absence of CXCR4 in humans. Contrary to the CCR5 receptor, the block of the CXCR4 leads to serious problems as the chemokine SDF1 can only interact with CXCR4, and currently, CXCR4 knockout mice are nonviable. The CXCR4 antagonist AMD3100 showed very promising results in cell culture experiments, but produced such severe side effects that the clinical studies had to beaborted. AMD887, AMD070 or AMD1170, other drugs from this series, are currently being tested [65-68].

\section{Fusion Inhibitors}

The helical regions HR1 and HR2 of the viral gp41, exposed after coreceptor binding of gp120, anchor the cellular membrane and lead to the fusion of both cellular and viral membranes. The fusion inhibitor enfuvirtide (T-20, Fuzeon ${ }^{\circledR}$, Hoffmann-La Roche) is an HR2-analog 36-amino-acid-long peptide which binds to the HR1 sequence and inhibits the fusion event [reviewed in 69]. It is active against HIV-1 R5 and X4 viruses, but not against HIV-2. The peptide sequence is derived directly from HXB2, one of the first laboratory-adapted HIV-1 strains [70]. Similar fusogenic peptides are found in other viruses like Ebola and SARS [22]. The peptidic nature of T-20 constrains its method of administration. The lyophilized T-20 powder is reconstituted and must be administered twice daily by subcutaneous injection. Apart from the occurrence of injection site reactions, it is generally well tolerated. Mutations in the gp 41 amino acids 36-45 (corresponding to the HR1 domain) have been related to T-20 resistance and therapy failure [71]. Other fusion inhibitors such as TRI1144 [TR-0291144 (Trimeris)], sifuvirtide (FusoGen), CP32 or SC34EK are under development $[44,72]$ (see also http://www.trimeris.com/ 300Pipeline.aspx).

\section{Reverse Transcription Inhibitors}

After capsid liberation into the cytoplasm, capsid and nucleocapsid disassemble (uncoating), yet the precise mechanism is still not known [73]. Genomic RNA is associated with viral tRNA ${ }^{\text {Lys }}$ and with several viral proteins like RT, IN, PR, Vpr and MA constituting the reverse transcription complex (RTC) [74-76]. The RTC uses the microtubule system for transport through the cyto- plasm $[77,78]$. Within the RTC, reverse transcription of viral RNA into DNA takes place, conducted by the viral $\mathrm{RT}$, although the efficacy of reverse transcription is highly dependent on the presence of all components of the RTC. For instance, in the absence of IN protein, the reverse transcription is completely blocked [79].

The RT is an RNA-dependent DNA polymerase which produces double-stranded DNA from single-stranded RNA. This process starts with the synthesis of one singlestranded DNA in minus orientation copied from the viral RNAs, which is used as template for the subsequent synthesis of the second DNA strand. RT is a heteromeric enzyme that comprises a regulator subunit (p51) and a catalytic subunit (RNase $\mathrm{H}$ - p15) building the p66 molecule.

The p66 resembles a right hand, where the subdomains are designated fingers, palm and thumb. The catalytic site lies in the palm and comprises the amino acids D185-D186 and D110, a very conserved motif also in other RTs and polymerases [80]. It includes the viral ribonuclease $\mathrm{H}$ activity, responsible for the degradation of the template RNA from the DNA/RNA hybrid.

Since HIV-1 RT is reported not to maintain sustained replication longer than for approximately 100-200 bases, reverse transcription is the replication step with the highest probability for recombination events between the two strains of HIV-1 RNA in each particle [79, 81]. Similar to all RNA polymerases, HIV RT has a high error rate when transcribing RNA into DNA since it has no proofreading ability [82]. This high error rate, in combination with the high recombination rate, allows mutations to accumulate at an accelerated rate, resulting in important implications for immune escape, drug resistance development and tropism switch, among others [83].

\section{Nucleoside/Nucleotide RT Inhibitors ('Nukes')}

Both nucleoside and nucleotide RT inhibitors (NRTIs and NtRTIs) (table 1) are analogs of the natural substrates used to synthesize viral DNA, and they compete with them for incorporation into the growing viral DNA chain. However, NRTIs and NtRTIs lack a 3'-hydroxyl group on the deoxyribose moiety, so subsequent incorporation of nucleotides into the nascent DNA is blocked.

Resistance to NRTIs/NtRTIs can be achieved by selection of HIV strains with accumulated mutations in the RT coding region of the pol gene [reviewed in 84]. Two main mechanisms of resistance to NRTIs/NtRTIs are described: (1) mutations such as A62V, K65R, L74V, V75T/I, F77L, Y115F, F116Y, V118I, Q151M and M184V that reduce the RT affinity for the drugs favoring the incorporation of the natural substrates [85-87], and (2) the so- 


\begin{tabular}{llll}
\hline Drug & Abbreviation & Trade name & Company \\
\hline Zidovudine & AZT, ZDV & Retrovir & ViiV Healthcare (GlaxoSmithKline) \\
Stavudine & d4T & Zerit & Bristol-Myers Squibb \\
Lamivudine & 3TC & Epivir & ViiV Healthcare (GlaxoSmithKline) \\
Didanosine & ddI & Videx & Bristol-Myers Squibb \\
Zalcitabine & ddC & Hivid & Hoffmann-La Roche \\
Abacavir & ABC & Ziagen & ViiV Healthcare (GlaxoSmithKline) \\
Tenofovir & TDF & Viread & Gilead \\
Emtricitabine & FTC & Emtriva & Gilead \\
\hline
\end{tabular}

Table 2. NNRTIs

\begin{tabular}{llll}
\hline Drug & Abbreviation & Trade name & Company \\
\hline Delaviridine & DLV & Rescriptor & Pfizer \\
Nevirapine & NVP & Viramune & Boehringer Ingelheim \\
Efavirenz & EFV & Sustiva/Stocrin & Bristol-Myers Squibb \\
Etravirine (TMC 125) & ETR & Intelence & Tibotec \\
Rilpivirine (TMC 278) & RPV & - & Tibotec \\
\hline
\end{tabular}

called thymidine analog mutations (TAMs) 41L, D67N, K70R, L210W, T215Y and K219Q/E that increase the excision of already-incorporated NRTIs/NtRTIs [86, 8894].

There are also certain mutations in the pol gene that appear significantly more frequently in NRTI/NtRTI-exposed patients than in naive ones, although no direct correlation between these mutations and NRTI/NtRTI therapy failure has been detected. These mutations, located in the $6^{*}$ region (immediately $5^{\prime}$ of the PR), increase the incorporation of RT molecules in the progeny viruses [95].

\section{Nonnucleoside RT Inhibitors}

NNRTIs (table 2) block RT by binding at a hydrophobic pocket in the HIV-1 p66 unit, close to the active center of the enzyme. NNRTIs are not incorporated into the viral DNA (noncompetitive inhibitors of the RT), but instead inhibit the movement of RT domains needed to synthesize the DNA. NNRTIs are generally inactive against HIV-2 RT enzymes due to naturally occurring amino acid polymorphisms. The same substitutions, which are not present in the HIV-1 viruses of untreated individuals, can be selected under drug pressure leading to resistance to NNRTIs. Mutations leading to resistance to NNRTIs affect the tertiary structure or charge of the RT [reviewed in 84,96$]$. Since the lipophylic binding pocket is built mainly by three sites of the amino acid primary sequence, all but one of the NNRTI resistance mutations observed can be found in these regions (aa 98-108, 178-190, 225238). The only exception is located at RT amino acid position 138 of the RT enzyme, which is associated with rilpivirine resistance and may be involved in etravirine resistance [71].

NNRTIs display a low genetic barrier so their high effectiveness can be impaired by one mutation [97]. However, resistance to the two members of the second-generation NNRTIs etravirine (ETR) or rilpivirine (RPV), diarylpyrimidin-(DAPY)-analogs designed to avoid cross-resistance with nevirapine (NVP) and efavirenz $(\mathrm{EFV})$, requires the development of a higher number (24) of resistance mutations [98]. NNRTIs have a long plasmatic half-life, which allows a once-daily administration but represents a problem when therapy is discontinued. In this situation, suboptimal concentrations of the drugs may remain in the plasma for up to several weeks, favoring a rapid emergence of NNRTI resistance mutations [99].

\section{Integration Inhibitors}

Once DNA is synthesized in the RTC, the complex is named the preintegration complex. The preintegration complex docks to the nuclear membrane via viral Vpr and most likely some cellular factors [100-103]. Subse- 


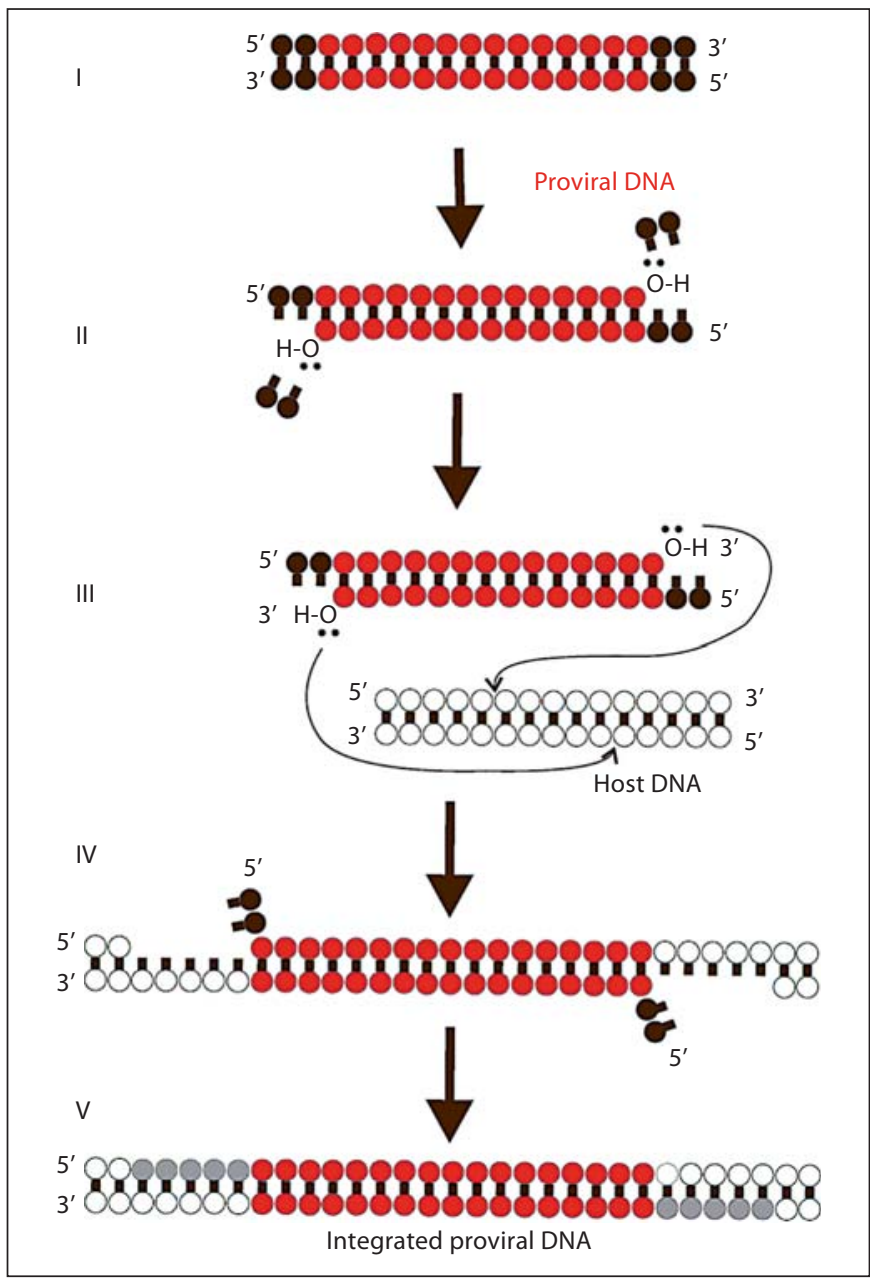

Fig. 3. HIV-1 integration. HIV-1 DNA (I); IN-catalyzed 3' processing: 2 nucleotides are removed from one or both $3^{\prime}$ ends of the viral DNA to expose the invariant cytosine-adenosine dinucleotides at both $3^{\prime}>$ ends of the viral DNA (II); IN-catalyzed strand transfer: the processed $3^{\prime}$ ends of the viral DNA are covalently ligated to the host chromosomal DNA (III); product of strand transfer (IV); DNA repair by cellular enzymes (V) [from 150].

quently, MA, IN and other proteins direct the preintegration complex to enter the nucleus through the nuclear pore $[104,105]$. There, the viral IN, which also has an endonuclease activity, inserts the proviral DNA genome into the chromosomal host DNA [reviewed in 106]. The integration of viral DNA is an essential step required to complete the life cycle of HIV. It also makes the host cell a permanent carrier of the viral genome, responsible for the persistence of retroviral infection. The integration process comprises two main steps (fig. 3): priming of the DNA ends by generating two bases of single-stranded
DNA at each end, and transfer of the proviral DNA into the host genome [reviewed in 106].

HIV-1 IN comprises three canonical domains, connected by flexible linkers: (1) the N-terminal domain (amino acids 1-50), including an $\mathrm{HH}-\mathrm{CC}$ zinc-binding motive, (2) the catalytic core domain (aa 51-212), containing the active centre (DDE motif, D64, D116 and E152), and (3) the C-terminal domain (aa 213-288), which allows the binding to the cellular DNA. The active form of the enzyme is believed to be a tetramer, a dimer of homodimers [107].

\section{IN Inhibitors}

Different substances are currently under development but only one licensed for clinical use belongs to the socalled strand transfer inhibitors. These drugs bind to the IN close to the DDE motif in the active site and competitively block the IN activity. The proviral DNA cannot be inserted into the host genome and is circularized by cellular repair enzymes, stopping the viral replication irreversibly $[108,109]$.

Raltegravir (RAL, Isentress ${ }^{\circledR}$, Merck) is a strand transfer inhibitor with potent activity against HIV-1 and HIV2 [110]. RAL is administered orally twice daily, does not require boosting with RTV and is well tolerated. Results from clinical trials indicate that RAL is safe and highly effective in the treatment of both antiretroviral-naive and antiretroviral-experienced patients [111-114]. Resistance to RAL has been associated with amino acid substitutions at three key positions in the IN protein: Y143R/C, Q148H/ $\mathrm{R} / \mathrm{K}$ or $\mathrm{H} 155 \mathrm{H}$, alone, or accompanied by other mutations such as T66I, L74M, E92Q, T97A, E138K+G140S/A GY143H, V151I and G163R [115-122].

Elvitegravir (EVG, GS-9137, Gilead), a second strand transfer inhibitor, is undergoing a phase III clinical trial (http://www.gilead.com/pr_1177855, accessed August 2010). It is also active against HIV-1 and HIV-2 [123-127]. EVG presents the advantage of an oral once-daily dosage, when boosted with RTV [125]. Resistance to EVG is associated with the mutations T66I/A/K, E92Q, E138K, Q146P, S147G, Q148R/H/K and N155H [128], which are close to the resistance mutations selected by RAL; therefore, cross-resistance for both drugs is expected [119, 129]. Other drugs under current development are reviewed in Serrao et al. [130].

\section{Inhibitors of the Viral Maturation}

If the integrated viral DNA does not lie dormant, it is transcribed by cellular RNA polymerase II and the resulting $\mathrm{mRNAs}$ are translated by the cellular ribosomes, under 


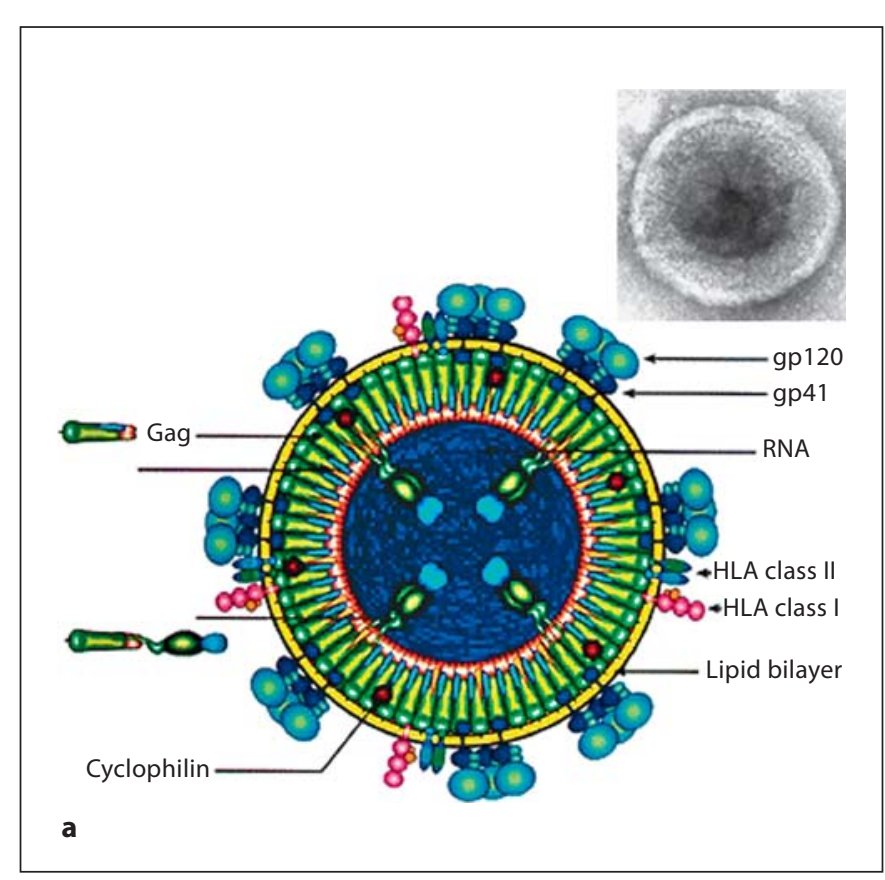

Fig. 4. Models for retroviral structure: immature (a) and mature (b) HIV-1 virions. a The Gag and Gag-Pol proteins are shown in different colors to suggest the domains corresponding to the mature proteins formed from these precursors. The surface and transmembrane components of Env are shown jutting out from the lipid membrane, as are HLA host proteins selectively incorpo-

coordination by cellular factors as well as viral accessory proteins [131]. The viral proteins, as well as tRNA ${ }^{\text {Lys }}$, genomic RNA and a number of cellular proteins start to assemble at the plasma membrane in a process orchestrated mainly by Gag $[76,132,133]$. The core of immature virions consists of uncleaved, radially arranged Gag polyproteins which interact with the Env proteins (fig. 4). Therefore, correct proteolytic Gag processing and core assembly are essential for viral infectivity [134-138]. The maturation process can be pharmacologically targeted via two different approaches: by interacting with the viral PR or with the Gag(-Pol) polyproteins (maturation inhibitors).

\section{Protease Inhibitors}

HIV-1 PR is an aspartic protease which is active as a homodimer. The active site lies between the two 99-amino-acid-long subunits and has the characteristic DTG (D25, T26 and G27) sequence common to aspartic PRs. The two D25 residues (one from each chain) act as the catalytic residues. PIs (table 3 ) are substrate analogs binding highly specific and reversibly to the active site of the enzyme. Resistance to PIs is achieved through mutations

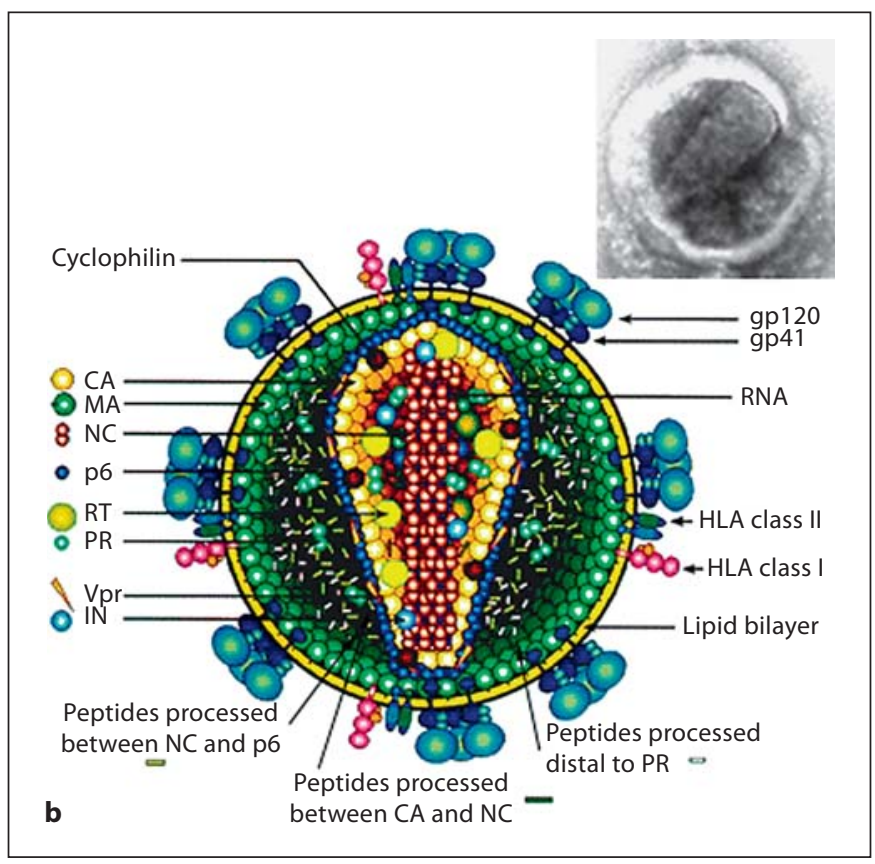

rated into HIV particles. Cyclophilin is also a host protein specific for HIV-1 group $\mathrm{M}$ virions. b Major Gag (CA = capsid protein; $\mathrm{MA}=$ matrix protein) and Pol proteins and the cone-shaped core characteristic of viruses of this genus. Vpr is an HIV accessory protein [adapted from 151].

located in the substrate-binding pocket (D30N, V32I, L33F, M46I/L, I47A/V, G48V, I50L/V, V82A/F/L/S/T and I84V) leading to conformational changes in the PR that reduce PI incorporation or binding. However, due to these conformational changes the overall fitness of the virus is reduced by these mutations, so compensatory (or secondary) mutations are needed to hold on to viral fitness [139, 140]. Last-generation PIs like tipranavir (TPV) and darunavir (DRV) were designed with the additional aim of avoiding class-embracing drug resistance, which was severely limiting 'classic' PI therapy. Designing such PIs followed certain criteria, e.g. interaction with peptidic chainbuilding atoms of viral amino acids only, instead of those in amino acid residues, in order to make the drug less susceptible to resistance. Although already the first-generation PIs were described as having relatively high genetic barriers to drug resistance, the last-generation PIs are drugs with very high genetic barriers, requiring the accumulation of 3-10 resistance mutations for the development of clinically relevant drug resistance [141]. In clinical practice, drug resistance to PIs is achieved gradually, after the accumulation of several PI resistance mutations. 
Table 3. PIs

\begin{tabular}{llll}
\hline Drug & Abbreviation & Trade name & Company \\
\hline Saquinavir & SQV & Invirase & Hoffmann-La Roche \\
Ritonavir & RTV & Norvir & Abbott \\
Indinavir & IDV & Crixivan & Merck \\
Nelfinavir & NFV & Viracept & Pfizer \\
Amprenavir & APV & Agenerase & ViiV Healthcare (GlaxoSmithKline) \\
Fosamprenavir & FPV & Telzir & ViiV Healthcare (GlaxoSmithKline) \\
Lopinavir/Ritonavir & LPV/r & Kaletra & Abbot \\
Atazanavir & ATV & Reyataz & Bristol-Myers Squibb \\
Tipranavir & TPV & Aptivus & Boehringer Ingelheim \\
Darunavir (TMC114) & DRV & Prezista & Tibotec \\
\hline
\end{tabular}

The impressive success of recent PIs cannot be explained only by the high genetic barrier, but also by their high efficacy. Both efficacy and the high genetic barrier could be improved by a third effect, boosting. Most PIs are metabolized by cytochrome P-450 CYP3A4 [142]. While being metabolized, PIs can induce and block the enzyme complex effectively and therefore cause severe drug interactions. Both are true for RTV, an effective PI itself but with displeasing side effects in most of the patients. RTV is used today in low dosages (100-200 mg) to reduce the liver metabolism of concomitantly administered, P-450 CYP3A4-degraded PIs (boosting). RTV boosting diminishes drug level variability in patients' plasma, eliminates food requirements and permits easier dosing schedules of PIs.

\section{Maturation Inhibitors}

Maturation inhibitors are drugs targeting one or more cleavage sites within the Gag precursor proteins or inhibiting capsid protein interactions required for core condensation. Bevirimat (PA-457; Myriad Pharmaceuticals) is the first compound in the class, although the drug has not yet been approved by the FDA and EMEA. Bevirimat is inactive against HIV-2. HIV-1 mutations conferring resistance to bevirimat were located in the cleavage site P24/P2 (H358Y, L363M/F, A364I/M/V and A366V/T) and in P2 peptide (Q369H, V370A/M/del and T371del), either increasing the cleavage rate at site $\mathrm{P} 24 / \mathrm{P} 2$ by the viral PR or interfering with the binding of the drug [143145]. Unfortunately, the effectiveness of bevirimat therapy is impaired by HIV-1 polymorphisms in P2 (amino acids 369-371), naturally occurring in 30-40\% of HIV-1 therapy-naive isolates. In addition, coevolution of HIV PR and Gag mutations has been observed during PI ex- posure [146], and PI treatment failures increase the prevalence of resistance to bevirimat and reduce clinical outcome during bevirimat therapy [147].

\section{Conclusions}

The use of antiretroviral combination therapy has proven to be effective against the progression to AIDS in HIV-infected individuals. During the last 5 years, the introduction of two new PIs (DRV and TPV) with broad activities against PI-resistant viral strains, the CCR 5 antagonist maraviroc, the IN inhibitor RAL, and the second-generation NNRTI ETR, has tremendously increased the efficacy of antiretroviral treatment [148, 149]. Meanwhile, successfully treated HIV infection can be considered a chronic disease instead of a deadly infection. However, the success of antiretroviral therapy is limited by high costs, viral resistance development and side effects. Eradication of the virus from the infected body by antiretroviral combination therapy or a cure of HIV infection is still not possible. Additional targets will have to be defined to achieve the goal of medical intervention in HIV infection: a worldwide perspective to survive an HIV infection to a normal life expectancy.

\section{Acknowledgments}

This work was supported by the Resin Project (BMG IIA52010-2510AUK361), CHAIN Project (EU-223131), EURESIST project (IST-4-027173), Messy project (BMBF-0315489C) and CORUS Project (BMBF 01ES0712). 


\section{References}

1 Schuurman R, Nijhuis M, van Leeuwen R, Schipper P, de Jong D, Collis P, Danner SA, Mulder J, Loveday C, Christopherson C, et al: Rapid changes in human immunodeficiency virus type 1 RNA load and appearance of drug-resistant virus populations in persons treated with lamivudine (3TC). J Infect Dis 1995;171:1411-1419.

- 2 Staszewski S: Zidovudine and lamivudine: results of phase III studies. J Acquir Immune Defic Syndr Hum Retrovirol 1995;10(suppl 1):S57.

-3 Grob PM, Wu JC, Cohen KA, Ingraham RH, Shih CK, Hargrave KD, McTague TL, Merluzzi VJ: Nonnucleoside inhibitors of HIV-1 reverse transcriptase: nevirapine as a prototype drug. AIDS Res Hum Retroviruses 1992;8:145-152.

4 Kohl NE, Emini EA, Schleif WA, Davis LJ, Heimbach JC, Dixon RA, Scolnick EM, Sigal IS: Active human immunodeficiency virus protease is required for viral infectivity. Proc Natl Acad Sci USA 1988;85:4686-4690.

5 Larder BA: Viral resistance and the selection of antiretroviral combinations. J Acquir Immune Defic Syndr Hum Retrovirol 1995; 10(suppl 1):S28-S33.

6 Vella S: Rationale and experience with reverse transcriptase inhibitors and protease inhibitors. J Acquir Immune Defic Syndr Hum Retrovirol 1995;10(suppl 1):S58-S61.

7 Cohen J: AIDS therapy: failure isn't what it used to be...but neither is success. Science 1998;279:1133-1134.

-8 Carr A, Samaras K, Burton S, Law M, Freund J, Chisholm DJ, Cooper DA: A syndrome of peripheral lipodystrophy, hyperlipidaemia and insulin resistance in patients receiving HIV protease inhibitors. AIDS 1998;12:F51F58.

9 Walmsley S, Bernstein B, King M, Arribas J, Beall G, Ruane P, Johnson M, Johnson D, Lalonde R, Japour A, Brun S, Sun E: Lopinavir-ritonavir versus nelfinavir for the initial treatment of HIV infection. N Engl J Med 2002;346:2039-2046.

-10 Rodriguez-French A, Boghossian J, Gray GE, Nadler JP, Quinones AR, Sepulveda GE, Millard JM, Wannamaker PG: The NEAT study: a 48-week open-label study to compare the antiviral efficacy and safety of GW433908 versus nelfinavir in antiretroviral therapynaive HIV-1-infected patients. J Acquir Immune Defic Syndr 2004;35:22-32.

11 Westby M, Smith-Burchnell C, Mori J, Lewis M, Mosley M, Stockdale M, Dorr P, Ciaramella G, Perros M: Reduced maximal inhibition in phenotypic susceptibility assays indicates that viral strains resistant to the CCR5 antagonist maraviroc utilize inhibitorbound receptor for entry. J Virol 2007;81: 2359-2371.
12 Abbate I, Vlassi C, Rozera G, Bruselles A, Bartolini B, Giombini E, Corpolongo A, D’Offizi G, Narciso P, Desideri A, Ippolito G, Capobianchi MR: Detection of quasispecies variants predicted to use CXCR4 by ultradeep pyrosequencing during early HIV infection. AIDS 2011;25:611-617.

-13 Farnet CM, Bushman FD: HIV cDNA integration: molecular biology and inhibitor development. AIDS 1996;10(suppl A):S3-S11.

14 Smart T: The first integrase inhibitor. GMHC Treat Issues 1996;10:8-9.

15 DeJesus E, Berger D, Markowitz M, et al: The HIV integrase inhibitor GS-9137 (JTK-303) exhibits potent antiviral activity in treatment-naive and experienced patients. 13th Conference on Retroviruses and Opportunistic Infections, Denver, 2006, abstract LB160.

16 Morales-Ramirez JO, Teppler H, Kovacs C, Steigbigel RT, Cooper D, Liporace RL, Schwartz R, Wenning L, Zhao J, Gilde L, Isaacs R, Nguyen BY, Protocol 004 Team: Antiretroviral effect of MK-0518, a novel HIV-1 integrase inhibitor, in ART-naive HIV-infected patients. 10th European AIDS Conference, Dublin, 2005, abstract LBPS1/6.

17 Chang LJ, Chen YM, Chen MY, Chou CC, Twu SJ, Huang LM: HIV 10 years later where do we stand now? J Biomed Sci 1995;2: $1-11$.

18 McDougal JS, Nicholson JK, Cross GD, Cort SP, Kennedy MS, Mawle AC: Binding of the human retrovirus HTLV-III/LAV/ARV/HIV to the CD4 (T4) molecule: conformation dependence, epitope mapping, antibody inhibition, and potential for idiotypic mimicry. J Immunol 1986;137:2937-2944.

19 Clapham PR, McKnight A: Cell surface receptors, virus entry and tropism of primate lentiviruses. J Gen Virol 2002;83:1809-1829.

20 Moore JP, Kitchen SG, Pugach P, Zack JA: The CCR5 and CXCR4 coreceptors - central to understanding the transmission and pathogenesis of human immunodeficiency virus type 1 infection. AIDS Res Hum Retroviruses 2004;20:111-126.

21 Reeves JD, Hibbitts S, Simmons G, McKnight A, Azevedo-Pereira JM, MonizPereira J, Clapham PR: Primary human immunodeficiency virus type 2 (HIV-2) isolates infect CD4-negative cells via CCR5 and CXCR4: comparison with HIV-1 and simian immunodeficiency virus and relevance to cell tropism in vivo. J Virol 1999;73:77957804.

22 Steffen I, Pohlmann S: Peptide-based inhibitors of the HIV envelope protein and other class I viral fusion proteins. Curr Pharm Des 2010;16:1143-1158.

23 Moore JP, Jameson BA, Weiss RA, Sattentau QJ: The HIV-cell fusion reaction; in Bentz J (ed): Viral Fusion Mechanisms. Boca Raton, CRC Press, 1993, pp 233-290.
24 Weiss RA: Cellular receptors and viral glycoproteins involved in retrovirus entry; in Levy JA (ed): The Retroviridae. New York, Plenum Press, 1993, pp 1-108.

25 Pan C, Liu S, Jiang S: HIV-1 gp41 fusion intermediate: a target for HIV therapeutics. J Formos Med Assoc 2010;109:94-105.

-26 Fisher RA, Bertonis JM, Meier W, Johnson VA, Costopoulos DS, Liu T, Tizard R, Walker BD, Hirsch MS, Schooley RT, et al: HIV infection is blocked in vitro by recombinant soluble CD4. Nature 1988;331:76-78.

27 Yee M, Konopka K, Balzarini J, Duzgunes N: Inhibition of HIV-1 env-mediated cell-cell fusion by lectins, peptide T-20, and neutralizing antibodies. Open Virol J 2011;5:44-51.

28 Chen W, Dimitrov DS: Human monoclonal antibodies and engineered antibody domains as HIV-1 entry inhibitors. Curr Opin HIV AIDS 2009;4:112-117.

29 Daar ES, Li XL, Moudgil T, Ho DD: High concentrations of recombinant soluble CD4 are required to neutralize primary human immunodeficiency virus type 1 isolates. Proc Natl Acad Sci USA 1990;87:6574-6578.

30 Teixeira C, Gomes JR, Gomes P, Maurel F: Viral surface glycoproteins, gp120 and gp41, as potential drug targets against HIV-1: brief overview one quarter of a century past the approval of zidovudine, the first anti-retroviral drug. Eur J Med Chem 2011;46:979-992.

31 Norris D, Morales J, Godofsky E, García F, Hardwicke R, Lewis S: TNX-355, in combination with optimized background regimen (OBR), achieves statistically significant viral load reduction and CD4 cell count increase when compared with OBR alone in phase 2 study at 48 weeks. 16th International AIDS Conference, Toronto, 2006, pp (abstract) ThLB0218.

32 Kuritzkes DR, Jacobson JM, Powderly W, Godofsky E, De Jesus E, Haas F, Reimann KA, Yarbough P, Curt VR, Shanahan WR: Safety and preliminary anti-HIV activity of an anti-CD4 mAb (TNX-355; Formerly Hu5A8) in HIV-infected patients. 10th Conference on Retroviruses and Opportunistic Infections, Boston, 2003, abstract 13.

-33 Jacobson JM, Israel RJ, Lowy I, Ostrow NA, Vassilatos LS, Barish M, Tran DN, Sullivan BM, Ketas TJ, O’Neill TJ, Nagashima KA, Huang W, Petropoulos CJ, Moore JP, Maddon PJ, Olson WC: Treatment of advanced human immunodeficiency virus type 1 disease with the viral entry inhibitor PRO 542. Antimicrob Agents Chemother 2004;48: 423-429.

34 Lin PF, Blair W, Wang T, Spicer T, Guo Q, Zhou N, Gong YF, Wang HG, Rose R, Yamanaka G, Robinson B, Li CB, Fridell R, Deminie C, Demers G, Yang Z, Zadjura L, Meanwell N, Colonno R: A small molecule HIV-1 inhibitor that targets the HIV-1 envelope and inhibits CD4 receptor binding. Proc Natl Acad Sci USA 2003;100:11013-11018. 
35 Hanna G, Lalezari J, Hellinger J, D Wohl D, Masterson T, Fiske W, Kadow J, Lin PF, Giordano M, Colonno R, Grasela D: Antiviral activity, safety, and tolerability of a novel, oral small-molecule HIV-1 attachment inhibitor, BMS-488043, in HIV-1-infected subjects. 11th Conference on Retroviruses and Opportunistic Infections, San Francisco, 2004, abstract 141.

36 Si Z, Madani N, Cox JM, Chruma JJ, Klein JC, Schon A, Phan N, Wang L, Biorn AC, Cocklin S, Chaiken I, Freire E, Smith AB, 3rd, Sodroski JG: Small-molecule inhibitors of HIV-1 entry block receptor-induced conformational changes in the viral envelope glycoproteins. Proc Natl Acad Sci USA 2004 101:5036-5041.

- 37 Madani N, Perdigoto AL, Srinivasan K, Cox JM, Chruma JJ, LaLonde J, Head M, Smith AB 3rd, Sodroski JG: Localized changes in the gp120 envelope glycoprotein confer resistance to human immunodeficiency virus entry inhibitors BMS-806 and \#155. J Virol 2004;78:3742-3752.

38 Goodenow M, Huet T, Saurin W, Kwok S, Sninsky J, Wain-Hobson S: HIV-1 isolates are rapidly evolving quasispecies: evidence for viral mixtures and preferred nucleotide substitutions. J Acquir Immune Defic Syndr 1989;2:344-352.

-39 Nowak MA, May RM, Anderson RM: The evolutionary dynamics of HIV-1 quasispecies and the development of immunodeficiency disease. AIDS 1990;4:1095-1103.

-40 Daumer M, Kaiser R, Klein R, Lengauer T, Thiele B, Thielen A: Genotypic tropism testing by massively parallel sequencing: qualitative and quantitative analysis. BMC Med Inform Decis Mak 2011;11:30.

-41 Kitrinos KM, Amrine-Madsen H, Irlbeck DM, Word JM, Demarest JF: Virologic failure in therapy-naive subjects on aplaviroc plus lopinavir-ritonavir: detection of aplaviroc resistance requires clonal analysis of envelope. Antimicrob Agents Chemother 2009;53:1124-1131.

42 Liu R, Paxton WA, Choe S, Ceradini D, Martin SR, Horuk R, MacDonald ME, Stuhlmann H, Koup RA, Landau NR: Homozygous defect in HIV-1 coreceptor accounts for resistance of some multiply-exposed individuals to HIV-1 infection. Cell 1996;86: 367-377.

43 Mayer H, van der Ryst E, Saag M, Clotet B, Fätkenheuer G, Clumeck N, Turner K, Goodrich JM: Safety and efficacy of maraviroc, a novel CCR5 antagonist, when used in combination with optimized background therapy for the treatment of antiretroviral-experienced subjects infected with dual/mixedtropic HIV-1: 24-week results of a phase $2 b$ exploratory trial. 16th International AIDS Conference, Toronto, 2006, abstract ThLB0215.

44 Perry CM: Maraviroc: a review of its use in the management of CCR5-tropic HIV-1 infection. Drugs 2010;70:1189-1213.
45 van Lunzen J: How will CCR5 antagonists influence the recommendations for the antiretroviral treatment of HIV-1 infection. Eur J Med Res 2007; 12:435-440.

46 Mueller MC, Bogner JR: Treatment with CCR5 antagonists: which patient may have a benefit? Eur J Med Res 2007;12:441-452.

47 Hardy D, Reynes J, Konourina I, Wheeler D, Moreno S, van der Ryst E, Towner W, Horban A, Mayer H, Goodrich J: Efficacy and safety of maraviroc plus optimized background therapy in treatment-experienced patients infected with CCR5-tropic HIV-1: 48-week combined analysis of the MOTIVATE studies. 15th Conference on Retroviruses and Opportunistic Infections, Boston, 2008, abstract 792 .

48 Lewis M, Simpson P, Fransen S, Huang W, Whitcomb J, Moseley J, Robertson DL, Mansfield R, Ciaramella G, Westby M: CXCR4-using virus detected in patients receiving maraviroc in the phase III studies MOTIVATE 1 and 2 originates form a preexisting minority of CXCR4-using virus. Antiviral Ther 2007;12:S65.

49 Mori J, Mosley M, Lewis M, Simpson P, Toma J, Huang W, Whitcomb J, Ciaramella G, Westby M: Characterization of maraviroc resistance in patients failing treatment with CCR5-tropic virus in MOTIVATE 1 and MOTIVATE 2. Antiviral Ther 2007;12:S12.

50 Gulick RM, Lalezari J, Goodrich J, Clumeck N, DeJesus E, Horban A, Nadler J, Clotet B, Karlsson A, Wohlfeiler M, Montana JB, McHale M, Sullivan J, Ridgway C, Felstead S, Dunne MW, van der Ryst E, Mayer H: Maraviroc for previously treated patients with R5 HIV-1 infection. N Engl J Med 2008;359: 1429-1441.

51 Heera J, Saag M, Ive P, Whitcomb J, Lewis M, McFadyen L, Goodrich J, Mayer H, van der Ryst E, Westby M: Virological correlates associated with treatment failure at week 48 in the phase 3 study of maraviroc in treatmentnaive patients. 15th Conference on Retroviruses and Opportunistic Infections, Boston, 2008, pp (abstract) 40LB.

52 Saag M, Ive P, Heera J, Tawadrous M, DeJesus E, Clumeck N, Cooper D, Horban A, Mohapi L, Mingrone H, Reyes-Teran G, Walmsley S, Hackman F, van der Ryst E, Mayer H: A multicenter, randomized, double-blind, comparative trial of a novel CCR5 antagonist, maraviroc versus efavirenz, both in combination with Combivir (zidovudine [ZDV]/ lamivudine [3TC]), for the treatment of antiretroviral naive patients infected with $\mathrm{R} 5$ HIV 1: week 48 results of the MERIT study. 4th International AIDS Society Conference on HIV Pathogenesis, Treatment and Prevention (IAS), Sydney, 2007, abstract WESS104.
53 van der Ryst E, Mayer H, Goodrich JM, Turner K, Sullivan JF, Simpson P, Westby M: Selective suppression of R5 HIV-1 by the novel CCR5 antagonist maraviroc (MVC) is associated with maintenance of CD4 cell counts in antiretroviral-experienced patients (pts) infected with dual/mixed-tropic (D/M) HIV-1. 9th International Congress on Drug Therapy in HIV Infection, Glasgow, 2008, abstract P393.

54 Lewis M, Simpson P, Delogne C, Sullivan J, Valdez H, Harrigan RP, Westby M: Genotypic analysis of the HIV-1 gp120 V3 loop for treatment-experienced patients enrolled into the MOTIVATE studies and who received maraviroc + optimized background therapy. 17th Conference on Retroviruses and Opportunistic Infections, San Francisco, 2010, poster 539 .

55 Saracino A, Monno L, Brindicci G, Trillo G Altamura M, Punzi G, Lagioia A, Angarano G: Are the proposed env mutations actually associated with resistance to maraviroc? J Acquir Immune Defic Syndr 2010;53:550552.

56 Nichols WG, Steel HM, Bonny T, Adkison K, Curtis L, Millard J, Kabeya K, Clumeck N: Hepatotoxicity observed in clinical trials of aplaviroc (GW873140). Antimicrob Agents Chemother 2008;52:858-865.

57 Baba M, Takashima K, Miyake H, Kanzaki $\mathrm{N}$, Teshima K, Wang X, Shiraishi M, Iizawa Y: TAK-652 inhibits CCR5-mediated human immunodeficiency virus type 1 infection in vitro and has favorable pharmacokinetics in humans. Antimicrob Agents Chemother 2005;49:4584-4591

58 Baba M, Miyake H, Wang X, Okamoto M, Takashima K: Isolation and characterization of human immunodeficiency virus type 1 resistant to the small-molecule CCR5 antagonist TAK-652. Antimicrob Agents Chemother 2007;51:707-715.

59 Trkola A, Ketas TJ, Nagashima KA, Zhao L, Cilliers T, Morris L, Moore JP, Maddon PJ Olson WC: Potent, broad-spectrum inhibition of human immunodeficiency virus type 1 by the CCR 5 monoclonal antibody PRO 140. J Virol 2001;75:579-588

60 Giguel F, Beebe L, Migone TS, Kuritzke D: The anti-CCR5 mAb004 inhibits HIV-1 replication synergistically in combination with other antiretroviral agents but does not select for resistance during in vitro passage. 13th Conference on Retroviruses and $\mathrm{Op}$ portunistic Infections, Denver, 2006, abstract 505 .

61 Schurmann D, Rouzier R, Nougarede N, Reynes J, Fatkenheuer G, Raffi F, Michelet C, Tarral A, Hoffmann C, Kiunke J, Sprenger H, vanLier J, Sansone A, Jackson M, Laughlin M: Antiviral activity of a CCR5 receptor antagonist. 11th Conference on Retroviruses and Opportunistic Infections, Moscone West, 2004, abstract 140LB. 
62 Wang X, Douglas SD, Lai JP, Tuluc F, Tebas P, Ho WZ: Neurokinin-1 receptor antagonist (aprepitant) inhibits drug-resistant HIV-1 infection of macrophages in vitro. J Neuroimmune Pharmacol 2007;2:42-48.

63 Lai JP, Ho WZ, Kilpatrick LE, Wang X, Tuluc F, Korchak HM, Douglas SD: Full-length and truncated neurokinin-1 receptor expression and function during monocyte/ macrophage differentiation. Proc Natl Acad Sci USA 2006;103:7771-7776.

64 Wang X, Douglas S, Lai JP, Tebas P, Lathey J, Ho WZ: Neurokinin-1 receptor antagonist inhibits drug-resistant HIV-1 infection of monocyte-derived macrophages in vitro. 13th Conference on Retroviruses and Opportunistic Infections, Denver, 2006, abstract 511.

65 Hendrix CW, Stone N, Dunaway S, Flexner C, Calandra G, Wiggins I, Conley J, Snyder S, Tierney C: Biologic activity of an orally bioavailable CXCR4 antagonist in human subjects. 15th International AIDS Conference, Bangkok, 2004, pp (abstract) TuPeB4475.

66 Hazuda DJ, HIV-1 Integrase Inhibitor Discovery Team: A novel HIV-1 integrase inhibitor mediates sustained suppression of viral replication and CD4 depletion in a SHIV rhesus macaque model of infection. Antivir Ther 2002;7:S3.

67 Moyle G, DeJesus E, Boffito M, Wong R, Coakley E, Gibney C, Badel K, Calandra G, Bridger G, Becker S: CXCR4 Antagonism: Proof of activity with AMD11070. 14th Conference on Retroviruses and Opportunistic Infections, Los Angeles, 2007, abstract 511.

68 Saag M, Rosenkranz S, Becker S, Klingman K, Kallungal B, Zadzilka A, Coakley E, Acosta E, Calandra G, Johnson V, NIAID AIDS Clinical Trials Group B: Proof of concept of antiretroviral activity of AMD11070 (an orally administered CXCR4 entry inhibitor): results of the first dosing cohort A studied in ACTG protocol A5210. 14th Conference on Retroviruses and Opportunistic Infections, Los Angeles, 2007, abstract 512.

-69 Oldfield V, Keating GM, Plosker G: Enfuvirtide: a review of its use in the management of HIV infection. Drugs 2005;65:1139-1160.

-70 Ratner L, Haseltine W, Patarca R, Livak KJ, Starcich B, Josephs SF, Doran ER, Rafalski JA, Whitehorn EA, Baumeister $\mathrm{K}$, et al: Complete nucleotide sequence of the AIDS virus, HTLV-III. Nature 1985;313:277-284.

-71 Wei X, Decker JM, Liu H, Zhang Z, Arani RB, Kilby JM, Saag MS, Wu X, Shaw GM, Kappes JC: Emergence of resistant human immunodeficiency virus type 1 in patients receiving fusion inhibitor (T-20) monotherapy. Antimicrob Agents Chemother 2002;46: 1896-1905.
72 Dwyer JJ, Wilson KL, Davison DK, Freel SA, Seedorff JE, Wring SA, Tvermoes NA, Matthews TJ, Greenberg ML, Delmedico MK: Design of helical, oligomeric HIV-1 fusion inhibitor peptides with potent activity against enfuvirtide-resistant virus. Proc Natl Acad Sci USA 2007;104:12772-12777.

73 Arhel N: Revisiting HIV-1 uncoating. Retrovirology 2010;7:96.

74 Auewarakul P, Wacharapornin P, Srichatrapimuk S, Chutipongtanate S, Puthavathana P: Uncoating of HIV-1 requires cellular activation. Virology 2005;337:93-101.

75 Narayan S, Young JA: Reconstitution of retroviral fusion and uncoating in a cell-free system. Proc Natl Acad Sci USA 2004;101: 7721-7726.

76 Bukrinskaya A: HIV-1 matrix protein: a mysterious regulator of the viral life cycle. Virus Res 2007;124:1-11.

-77 McDonald D, Vodicka MA, Lucero G, Svitkina TM, Borisy GG, Emerman M, Hope TJ: Visualization of the intracellular behaviour of HIV in living cells. J Cell Biol 2002;159: 441-452.

78 Bukrinskaya A, Brichacek B, Mann A, Stevenson $\mathrm{M}$ : Establishment of a functional human immunodeficiency virus type 1 (HIV-1) reverse transcription complex involves the cytoskeleton. J Exp Med 1998;188:21132125 .

79 Leavitt AD, Robles G, Alesandro N, Varmus HE: Human immunodeficiency virus type 1 integrase mutants retain in vitro integrase activity yet fail to integrate viral DNA efficiently during infection. J Virol 1996;70:721728.

80 Heringa J, Argos P: Evolution of viruses as recorded by their polymerase sequences; in Morse SS (ed): The Evolutionary Biology of Viruses. New York, Raven Press, 1994, pp 87-103.

81 Sakuragi J, Sakuragi S, Ohishi M, Shioda T: Direct correlation between genome dimerization and recombination efficiency of HIV-1. Microbes Infect 2010;12:1002-1011.

82 Menendez-Arias L: Molecular basis of fidelity of DNA synthesis and nucleotide specificity of retroviral reverse transcriptases. Prog Nucleic Acid Res Mol Biol 2002;71:91-147.

83 Domingo E, Biebricher CK, Holland JJ, Eigen $M$ (eds): Quasispecies and RNA Virus Evolution: Principles and Consequences. Austin, Landes Bioscience, 2001.

84 Menendez-Arias L: Molecular basis of human immunodeficiency virus drug resistance: an update. Antiviral Res 2010;85:210-231.

85 Loveday C: International perspectives on antiretroviral resistance. Nucleoside reverse transcriptase inhibitor resistance. J Acquir Immune Defic Syndr 2001;26:S10-S24.

-86 Ray AS, Basavapathruni A, Anderson KS: Mechanistic studies to understand the progressive development of resistance in human immunodeficiency virus type 1 reverse transcriptase to abacavir. J Biol Chem 2002;277: 40479-40490.
87 Girouard M, Diallo K, Marchland B, McCormick S, Wainberg MA, Götte M: The V118I mutation in the reverse transcriptase of HIV1 diminishes the incorporation of multiple nucleoside analogue inhibitors. Antivir Ther 2002;7:S24.

88 Girouard M, Diallo K, Marchand B, McCormick S, Gotte M: Mutations E44D and V118I in the reverse transcriptase of HIV-1 play distinct mechanistic roles in dual resistance to AZT and 3TC. J Biol Chem 2003;278: 34403-34410.

89 Mas A, Parera M, Briones C, Soriano V, Martínez MA, Domingo E, Menéndez-Arias L: Role of a dipeptide insertion between codons 69 and 70 of HIV-1 reverse transcriptase in the mechanism of AZT resistance. EMBO J 2000;19:5752-5761.

90 Kuritzkes DR: Nucleoside reverse transcriptase inhibitors: resistance, cross-resistance, and resistance testing. The PRN notebook 2002;7:10-15.

91 Wolf E: Resistenzen; in Hoffmann C, Rockstroh JK, Kamps BS (eds): HIVNET 2007. Wuppertal-Beyenburg, Steinhäuser, 2007, pp 309-327.

92 Meyer PR, Matsuura SE, Mian AM, So AG, Scott WA: A mechanism of AZT resistance: an increase in nucleotide-dependent primer unblocking by mutant HIV-1 reverse transcriptase. Mol Cell 1999;4:35-43.

$\$ 93$ Meyer PR, Matsuura SE, So AG, Scott WA: Unblocking of chain-terminated primer by HIV-1 reverse transcriptase through a nucleotide-dependent mechanism. Proc Natl Acad Sci USA 1998:95:13471-13476.

-94 Meyer PR, Matsuura SE, Schinazi RF, So AG, Scott WA: Differential removal of thymidine nucleotide analogues from blocked DNA chains by human immunodeficiency virus reverse transcriptase in the presence of physiological concentrations of 2'-deoxynucleoside triphosphates. Antimicrob Agents Chemother 2000;44:3465-3472.

95 Peters S, Muñoz M, Yerly S, Sánchez-Merino V, López-Galíndez C, Perrin L, Larder B, Cmarko D, Fakan S, Meylan P, Telenti A: Resistance to nucleoside analog reverse transcriptase inhibitors mediated by human immunodeficiency virus type $1 \mathrm{p} 6$ protein. J Virol 2001;75:9644-9653.

96 Ren J, Stammers DK: Structural basis for drug resistance mechanisms for non-nucleoside inhibitors of HIV reverse transcriptase. Virus Res 2008;134:157-170.

97 Miller V, de Bethune MP, Kober A, Sturmer M, Hertogs K, Pauwels R, Stoffels P, Staszewski S: Patterns of resistance and crossresistance to human immunodeficiency virus type 1 reverse transcriptase inhibitors in patients treated with the nonnucleoside reverse transcriptase inhibitor loviride. Antimicrob Agents Chemother 1998;42:31233129. 
-98 Vingerhoets J, Azijn H, Fransen E, De Baere I, Smeulders L, Jochmans D, Andries K, Pauwels R, de Bethune MP: TMC125 displays a high genetic barrier to the development of resistance: evidence from in vitro selection experiments. J Virol 2005;79: 12773-12782.

99 Mackie NE, Fidler S, Tamm N, Clarke JR, Back D, Weber JN, Taylor GP: Clinical implications of stopping nevirapine-based antiretroviral therapy: relative pharmacokinetics and avoidance of drug resistance. HIV Med 2004;5:180-184.

100 Farnet CM, Haseltine WA: Determination of viral proteins present in the human immunodeficiency virus type 1 preintegration complex. J Virol 1991;65:1910-1915.

-101 Popov S, Rexach M, Zybarth G, Reiling N, Lee MA, Ratner L, Lane CM, Moore MS, Blobel G, Bukrinsky M: Viral protein R regulates nuclear import of the HIV-1 pre-integration complex. EMBO J 1998;17:909-917.

102 Jenkins Y, McEntee M, Weis K, Greene WC: Characterization of HIV-1 Vpr nuclear import: analysis of signals and pathways. J Cell Biol 1998;143:875-885.

103 Sherman MP, de Noronha CM, Heusch MI, Greene S, Greene WC: Nucleocytoplasmic shuttling by human immunodeficiency virus type 1 Vpr. J Virol 2001;75:1522-1532.

104 Le Rouzic E, Benichou S: The Vpr protein from HIV-1: distinct roles along the viral life cycle. Retrovirology 2005;2:11.

105 Haffar O, Bukrinsky M: Nuclear translocation as a novel target for anti-HIV drugs. Expert Rev Anti Infect Ther 2005;3:41-50.

106 Ramkumar K, Serrao E, Odde S, Neamati N: HIV-1 integrase inhibitors: 2007-2008 update. Med Res Rev 2010;30:890-954.

107 van Maele B, Debyser Z: HIV-1 integration: an interplay between HIV-1 integrase, cellular and viral proteins. AIDS Rev 2005;7: 26-43.

108 Hazuda DJ, Felock P, Witmer M, Wolfe A, Stillmock K, Grobler JA, Espeseth A, Gabryelski L, Schleif W, Blau C, Miller MD: Inhibitors of strand transfer that prevent integration and inhibit HIV-1 replication in cells. Science 2000;287:646-650.

109 Butler SL, Johnson EP, Bushman FD: Human immunodeficiency virus cDNA metabolism: notable stability of two-long terminal repeat circles. J Virol 2002;76:37393747.

110 Cahn P, Sued O: Raltegravir: a new antiretroviral class for salvage therapy. Lancet 2007;369:1235-1236.

-111 Markowitz M, Morales-Ramirez JO, Nguyen BY, Kovacs CM, Steigbigel RT, Cooper DA, Liporace R, Schwartz R, Isaacs R, Gilde LR, Wenning L, Zhao J, Teppler H: Antiretroviral activity, pharmacokinetics, and tolerability of MK-0518, a novel inhibitor of HIV-1 integrase, dosed as monotherapy for 10 days in treatment-naive HIV-1-infected individuals. J Acquir Immune Defic Syndr 2006;43:509-515.
112 Steigbigel R, Kumar P, Eron J, Schechter M, Markowitz M, Loufty M, Zhao J, Isaacs R, Nguyen BY, Teppler H, Group tB-S: Results of BENCHMRK-2, a phase III study evaluating the efficacy and safety of MK-0518, a novel HIV-1 integrase inhibitor, in patients with triple-class resistant virus. 14th Conference on Retroviruses and Opportunistic Infections, Los Angeles, 2007, abstract 105bLB.

113 Cooper D, Gatell J, Rockstroh J, Katlama C, Yeni P, Lazzarin A, Chen J, Isaacs R, Teppler H, Nguyen B, Group B-S: Results of BENCHMRK-1, a phase III study evaluating the efficacy and safety of MK-0518, a novel HIV-1 integrase inhibitor, in patients with triple-class resistant virus. 14th Conference on Retroviruses and Opportunistic Infections, Los Angeles, 2007, abstract 105aLB.

114 Grinsztejn B, Nguyen B, Katlama CB, Gatell J, Lazzarin A, Vittecoq D, Gonzalez C, Chen J, Isaacs R, Team TP: 48-week efficacy and safety of MK-0518, a novel HIV1 integrase inhibitor, in patients with tripleclass resistant virus. 47th Interscience Conference on Antimicrobial Agents and Chemotherapy, Chicago, 2007, abstract H-713.

115 Sichtig N, Sierra S, Kaiser R, Däumer MP, Reuter S, Schülter E, Altmann A, Fäktenheuer G, Dittmer U, Pfister H, Esser S: Raltegravir resistance mutation profiles: baseline situation and modification during treatment. J Antimicrob Chemother 2009; 64:25-32.

116 Lataillade M, Chiarella J, Kozal MJ: Natural polymorphism of the HIV-1 integrase gene and mutations associated with integrase inhibitor resistance. Antivir Ther 2007;12: 563-570.

117 Malet I, Delelis O, Valantin MA, Montes B, Soulie C, Wirden M, Tchertanov L, Peytavin G, Reynes J, Mouscadet JF, Katlama C, Calvez V, Marcelin AG: Mutations associated with failure of raltegravir treatment affect integrase sensitivity to the inhibitor in vitro. Antimicrob Agents Chemother 2008; 52:1351-1358.

118 Ceccherini-Silberstein F, Armenia D, D’Arrigo R, Micheli V, Fabeni L, Meraviglia P, Capetti A, Zaccarelli M, Trotta MP, Narciso P, Antinori A, Perno CF: Virological response and resistance in multi-experienced patients treated with raltegravir. Antiviral Ther 2008;13:A15.

119 McColl DJ, Fransen S, Gupta S, Parkin N, Margot N, Chuck S, Cheng AK, Miller MD: Resistance and cross-resistance to first generation integrase inhibitors: insights from a phase II study of elvitegravir (GS-9137). Antiviral Ther 2007;12:11.
120 Miller MD, Danovich RM, Ke Y, Witmer M, Zhao J, Harvey CM, Nguyen BY, Hazuda DJ: Longitudinal analysis of resistance to the HIV-1 integrase inhibitor reltegravir: results from P005, a phase II study in treatment-experienced patients. Antiviral Ther 2008; $13: \mathrm{A} 8$

121 Garrett N, Xu L, Smit E, Ferns B, El-Gadi S, Anderson J: Raltegravir treatment response in an HIV-2 infected patient: a case report. AIDS 2008;22:1091-1092.

122 Roquebert B, Blum L, Collin G, Damond F, Peytavin G, Leleu J, Matheron S, Chene G, Brun-Vezinet F, Descamps D: Selection of the Q148R integrase inhibitor resistance mutation in a failing raltegravir containing regimen. AIDS 2008;22:2045-2046.

123 Sato M, Motomura T, Aramaki H, Matsuda T, Yamashita M, Ito Y, Kawakami H, Matsuzaki Y, Watanabe W, Yamataka K, Ikeda S, Kodama E, Matsuoka M, Shinkai H: Novel HIV-1 integrase inhibitors derived from quinolone antibiotics. J Med Chem 2006; 49:1506-1508.

124 Matsuzaki Y, Watanabe W, Yamataka Kea: JTK-303/GS 9137, a novel small-molecule inhibitor of HIV-1 integrase: anti-HIV activity profile and pharmacokinetics in animals. 13th Conference on Retroviruses and Opportunistic Infections, Denver, 2006, abstract 508.

125 Kearny B, Mathias A, Zhong Lea: Pharmacokinetics/pharmacodynamics of GS-9137 an HIV integrase inhibitor in treatmentnaive and experienced patients. 7th International Workshop Clinical Pharmacology of HIV Therapy, Lisbon, 2006, abstract 73.

126 Zolopa A, Mullen M, Berger Dea: The HIV integrase inhibitor GS9137 demonstrates potent ARV activity in treatment-experienced patients. 14th Conference on Retroviruses and Opportunistic Infections, Los Angeles, 2007, abstract 143LB.

127 DeJesus E, Berger D, Markowitz M, Cohen C, Hawkins T, Ruane P, Elion R, Farthing C, Zhong L, Cheng AK, McColl D, Kearney BP: Antiviral activity, pharmacokinetics, and dose response of the HIV-1 integrase inhibitor GS-9137 (JTK-303) in treatmentnaive and treatment-experienced patients. J Acquir Immune Defic Syndr 2006;43:1-5.

128 Shimura K, Kodama E, Sakagami Y, Matsuzaki Y, Watanabe W, Yamataka K, Watanabe Y, Ohata Y, Doi S, Sato M, Kano M, Ikeda S, Matsuoka M: Broad antiretroviral activity and resistance profile of the novel human immunodeficiency virus integrase inhibitor elvitegravir (JTK-303/GS-9137). J Virol 2008;82:764-774.

129 Goethals O, Clyton R, Wagemans E, van Ginderen M, Vos AH, Geluykens P, Dockx $\mathrm{K}$, Hallenbereger S, Hertogs K: Resistance mutations in HIV-1 integrase selected with raltegravir or elvitegravir confer reduced susceptibility to a diverse panel of integrase inhibitors. Antiviral Ther 2008;13:A11. 
130 Serrao E, Odde S, Ramkumar K, Neamati $\mathrm{N}$ : Raltegravir, elvitegravir, and metoogravir: the birth of 'me-too' HIV-1 integrase inhibitors. Retrovirology 2009;6:25.

-131 Sierra S, Kupfer B, Kaiser R: Basics of the virology of HIV-1 and its replication. J Clin Virol 2005;34:233-244.

132 Greene WC, Peterlin BM: Charting HIV's remarkable voyage through the cell: basic science as a passport to future therapy. Nat Med 2002;8:673-680.

133 Jolly C, Mitar I, Sattentau QJ: Requirement for an intact T-cell actin and tubulin cytoskeleton for efficient assembly and spread of human immunodeficiency virus type 1 . J Virol 2007;81:5547-5560.

134 Briggs JA, Wilk T, Welker R, Krausslich HG, Fuller SD: Structural organization of authentic, mature HIV-1 virions and cores. EMBO J 2003;22:1707-1715.

135 Pettit SC, Everitt LE, Choudhury S, Dunn $\mathrm{BM}$, Kaplan AH: Initial cleavage of the human immunodeficiency virus type $1 \mathrm{Gag}$ Pol precursor by its activated protease occurs by an intramolecular mechanism. J Virol 2004;78:8477-8485.

136 Lanman J, Sexton J, Sakalian M, Prevelige PE Jr: Kinetic analysis of the role of intersubunit interactions in human immunodeficiency virus type 1 capsid protein assembly in vitro. J Virol 2002;76:6900-6908.

137 Wilk T, Gross I, Gowen BE, Rutten T, de Haas F, Welker R, Krausslich HG, Boulanger P, Fuller SD: Organization of immature human immunodeficiency virus type 1. J Virol 2001;75:759-771.
138 Ehrlich LS, Liu T, Scarlata S, Chu B, Carter CA: HIV-1 capsid protein forms spherical (immature-like) and tubular (mature-like) particles in vitro: structure switching by $\mathrm{pH}$-induced conformational changes. Biophys J 2001;81:586-594.

139 Johnson VA, Brun-Vezinet F, Clotet B, Kuritzkes DR, Pillay D, Schapiro JM, Richman DD: Update of the drug resistance mutations in HIV-1: fall 2006. Top HIV Med 2006;14:125-130.

140 Nijhuis M, Deeks S, Boucher C: Implications of antiretroviral resistance on viral fitness. Curr Opin Infect Dis 2001;14:2328.

141 Prabu-Jeyabalan MM, King NM, Nalivaika E, Scott WRP, Schiffer CA: Drug resistance and substrate recognition in HIV-1 protease. Antivir Ther 2002;7:S36.

142 Dietrich MA, Butts JD, Raasch RH: HIV-1 protease inhibitors: a review. Infect Med 1999; 16:716-738.

143 Zhou J, Chen CH, Aiken C: Human immunodeficiency virus type 1 resistance to the small molecule maturation inhibitor 3-O-(3', $3^{\prime}$-dimethylsuccinyl)-betulinic acid is conferred by a variety of single amino acid substitutions at the CA-SP1 cleavage site in Gag. J Virol 2006;80:1209512101.

144 Salzwedel K, Martin DE, Sakalian M: Maturation inhibitors: a new therapeutic class targets the virus structure. AIDS Rev 2007; 9:162-172.

145 Van Baelen K, Salzwedel K, Rondelez E, Van Eygen V, De Vos S, Verheyen A, Steegen K, Verlinden Y, Allaway GP, Stuyver LJ: Susceptibility of human immunodeficiency virus type 1 to the maturation inhibitor bevirimat is modulated by baseline polymorphisms in Gag spacer peptide 1. Antimicrob Agents Chemother 2009;53:21852188.
46 Malet I, Roquebert B, Dalban C, Wirden M, Amellal B, Agher R, Simon A, Katlama C, Costagliola D, Calvez V, Marcelin AG: Association of Gag cleavage sites to protease mutations and to virological response in HIV-1 treated patients. J Infect 2007;54: 367-374.

147 Verheyen J, Verhofstede C, Knops E, Vandekerckhove L, Fun A, Brunen D, Dauwe K, Wensing AM, Pfister H, Kaiser R, Nijhuis $\mathrm{M}$ : High prevalence of bevirimat resistance mutations in protease inhibitor-resistant HIV isolates. AIDS 2010;24:669-673.

148 Taiwo B, Murphy RL, Katlama C: Novel antiretroviral combinations in treatment-experienced patients with HIV infection: rationale and results. Drugs 2010;70:16291642.

149 Hughes CA, Robinson L, Tseng A, MacArthur RD: New antiretroviral drugs: a review of the efficacy, safety, pharmacokinetics, and resistance profile of tipranavir, darunavir, etravirine, rilpivirine, maraviroc, and raltegravir. Expert Opin Pharmacother 2009; 10:2445-2466.

150 Savarino A: In-silico docking of HIV-1 integrase inhibitors reveals a novel drug type acting on an enzyme/DNA reaction intermediate. Retrovirology 2007;4:21.

151 Vogt VM: Retroviral Virions and Genomes; in John M Coffin JM, Hughes SH, Varmus HE (eds): Retroviruses. Cold Spring Harbor, Cold Spring Harbor Laboratory Press, 1997. 